\title{
Aorticopulmonary Septal Defect
}

National Cancer Institute

\section{Source}

National Cancer Institute. Aorticopulmonary Septal Defect. NCI Thesaurus. Code C124495.

A cong enital heart malformation characterised by incomplete separation of the truncus arteriosus and the aorticopulmonary trunk, resulting in communication between the aorta and pulmonary trunk. 